\title{
Ptychoptera deleta Novák, I 877 from the Early Miocene of the Czech Republic: redescription of the first fossil attributed to Ptychopteridae (Diptera)
}

\author{
Wieslaw Krzemiński', Jakub Prokop ${ }^{2}$ \\ I Institute of Biology, Pedagogical University of Cracow, ul. Podbrzezie 3, 31-054 Kraków, Poland 2 Charles \\ University in Prague, Faculty of Science, Department of Zoology, Viničná 7, CZ-128 44, Praha 2, Czech Republic \\ Corresponding author: Jakub Prokop (jprokop@natur.cuni.cz) \\ Academic editor: D. Shcherbakov | Received 18 April 2011 | Accepted 20 July 2011 | Published 24 September 2011 \\ Citation: Krzemiński W, Prokop J (2011) Ptychoptera deleta Novák, 1877 from the Early Miocene of the Czech \\ Republic: redescription of the first fossil attributed to Ptychopteridae (Diptera). In: Shcherbakov DE, Engel MS, \\ Sharkey MJ (Eds) Advances in the Systematics of Fossil and Modern Insects: Honouring Alexandr Rasnitsyn. ZooKeys \\ 130: 299-305. doi: 10.3897/zookeys.130.1401
}

\section{Abstract}

The first fossil that was described in Ptychopteridae, Ptychoptera deleta Novák, 1877 from the classical Early Miocene locality Mokřina (Krottensee) in western Bohemia is re-examined. The re-description of the holotype including a new line drawing and remarks summarizing the scarce fossil record of this group is provided.

\section{Keywords}

Diptera, Ptychopteridae, Ptychoptera, revision, Tertiary, Neogene, Miocene, Ottnangian/Karpatian, Cypris Formation, Cheb Basin, Czech Republic

\section{Introduction}

The family Ptychopteridae is a very small group with about 70 Recent species belonging to two subfamilies (Ptychopterinae and Bittacomorphinae), mostly distributed in the Holarctic, Ethiopian and Oriental Regions. In the Neotropics one species is currently known (Hancock et al. 2006). Ptychopteridae are not present in the Australian and Antarctic Regions. The oldest true representative, Ptychoptera mesozoica Kalugina, 1989 was described from the Lower Cretaceous (Neocomian) of Baissa in Buryatia (Siberia, Russia). Ptychoptera deleta Novák, 1877, known from the Early Miocene of Mokřina (Krot-

Copyright Wieslaw Krzemiński, Jakub Prokop. This is an open access article distributed under the terms of the Creative Commons Attribution License, which permits unrestricted use, distribution, and reproduction in any medium, provided the original author and source are credited. 
tensee) in western Bohemia (Czech Republic), was the first described fossil representative of the family. Handlirsch (1909) supposed that the species did not belong to the genus Ptychoptera Meigen, 1803 and created a new genus Ptychopterula mainly on the basis of a considerably narrow wing base as present in Etoptychoptera Handlirsch, 1909 and a free Sc. However, he emphasized also the common characters present in Ptychopterula and the Recent genera Ptychoptera and Bittacomorpha Westwood, 1835 connection of R and Rs, the position of crossvein r-m, etc. Alexander (1927) also supposed that the species described by Novák did not belong to Ptychoptera. Peus (1958), in his monograph on the Ptychopteridae, referred to this species as Liriope ("Ptychopterula") deleta (Novák, 1877). These opinions were based on mistakenly Novak's drawing only, without revision of the holotype (see Fig. 2B). This paper presents a re-description of the holotype including a new line-drawing and photograph. Five other compressed fossil ptychopterid species were described till now: Ptychoptera miocenica (Cockerell, 1910) from the Oligocene of Florissant (Colorado, USA) originally placed in genus Bittacomorpha; Brodilka mitchelli Lukashevich, Coram \& Jarzembowski, 2001 and Zhiganka woolgari Lukashevich, Coram \& Jarzembowski, 2001 both from the Lower Cretaceous of Purbeck and Wealden groups (UK); Zhiganka comitans Lukashevich, 1995 from the Lower Cretaceous of Yakutia (Russia), and Probittacomorpha christenseni Freiwald \& Willmann, 1992 from

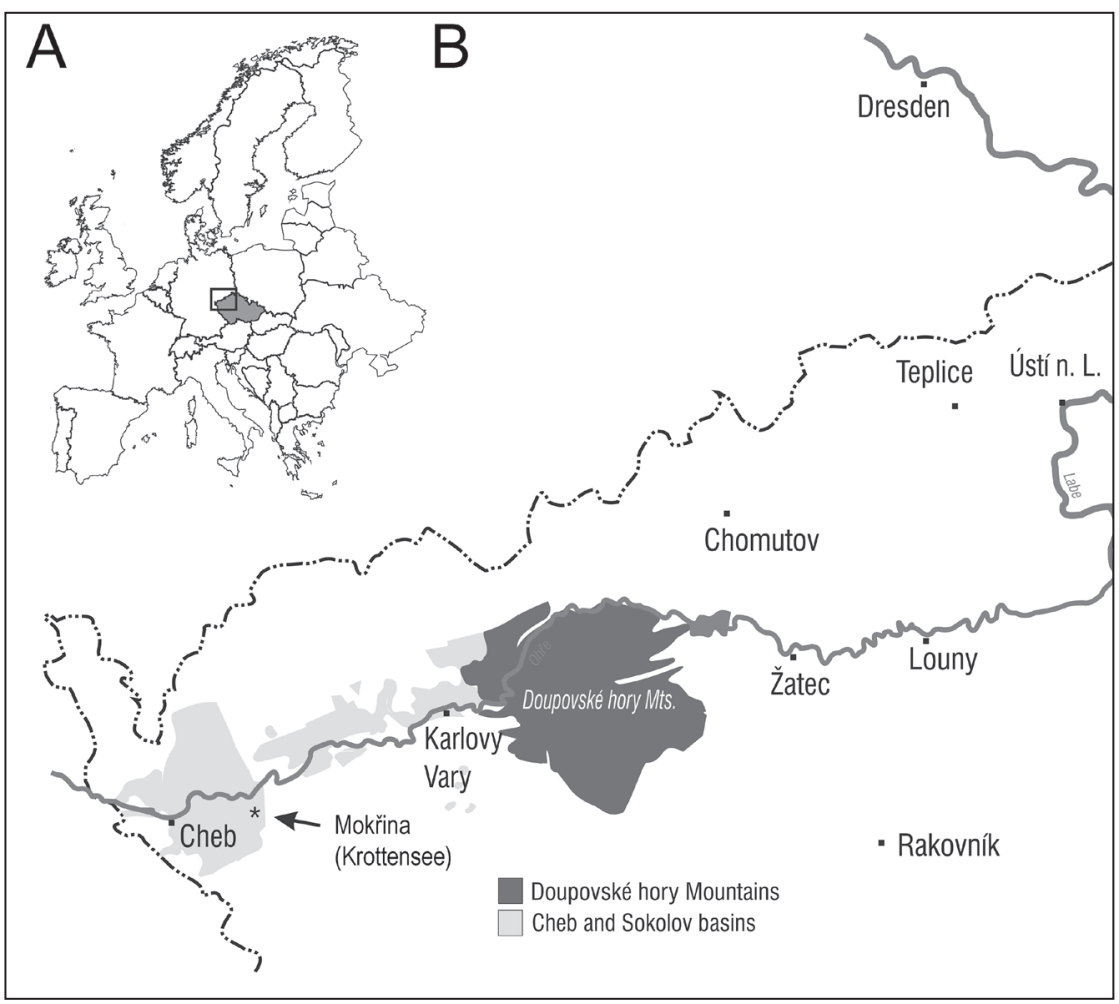

Figure I. A Geographical position of northwestern Bohemia within Europe B detailed map of the Cheb and Sokolov basins with indication of position of Mokřina (Krottensee) locality. 
the lowermost Eocene of Mo-clay (Denmark) (Freiwald and Willmann 1992; Evenhuis 1994; Lukashevich 1995; Ansorge and Schröder 1999; Lukashevich et al. 2001). Two genera, Zhiganka and Probittacomorpha are attributed to the subfamily Bittacomorphinae and others to Ptychopterinae. A single species, Ptychoptera eocenica Podenas, 2007 was described from an Eocene Baltic amber inclusion (Podenas 2007).

Lukashevich (2008) proposed a new system of Ptychopteroidea and synonymized the family Eoptychopteridae known from the Upper Triassic to Lower Cretaceous with Ptychopteridae. Eoptychopteridae is a considerably variable group of flies with common occurrence throughout the Jurassic up to the Lower Cretaceous (Kalugina 1989; Krzemiński 1992; Lukashevich 1993; Lukashevich et al. 1998; Ren and Krzemiński 2002; Krzemiński and Krzemińska 2003).

Novák (1877) described a fossil entomofauna from Mokřina (Krottensee) located in Cheb county of western Bohemia (Czech Republic) (Fig. 1). This classical Early Miocene locality in Cheb Basin yielded greenish marls of lake sedimentation belonging to the Cypris Formation (Rojík 2004). Fossiliferous layers previously called "Cypris shales" are well known for abundant occurrence of ostracods e.g. Cypris angusta (Reuss, 1852) when Cheb and Sokolov basins were interconnected (Obrhelová and Obrhel 1987). Mokrrina (Krottensee) locality belongs to biostratigraphic zone MN4 dated by mammals from nearby locality Dolnice (Fejfar 1974), and to ichthyozone IV defined by Obrhelová and Obrhel (1983). Fossil record from Mokřina is also well known by plants and bird remains (Bůžek et al. 1996; Mlíkovský 1996). Novák’s collection from Mokřina housed in National Museum in Prague contains 73 insect specimens classified in 10 families of five insect orders (Prokop et al. 2003).

\section{Material and methods}

The holotype specimen was observed under stereomicroscope Leica MZFLIII \& MZ16 in dry state. The line drawing of the venational pattern was drawn directly using a stereomicroscope and finally readjusted to the photograph scale using imageediting software (Adobe Photoshop CS). Photography was made simultaneously using a digital camera Canon PowerShot $S 80$ attached to the stereomicroscope. The type material referred to as 'NM' is housed at the National Museum in Prague, Czech Republic.

\section{Systematic paleontology}

Family Ptychopteridae Osten-Sacken, 1879

\section{Genus Ptychoptera Meigen, 1803}

Type species. Tipula contaminata Linnaeus, 1758 


\section{Ptychoptera deleta Novák, 1877}

http://species-id.net/wiki/Ptychoptera_deleta

Figs $2 \mathrm{~A}-\mathrm{C}$

Ptychoptera deleta Novák, 1877: p. 88, Pl. II, Fig.1.

Ptychopterula deleta (Novák, 1877): Handlirsch (1909): p. 264, 269.

Liriope (“Ptychopterula”) deleta (Novák, 1878): Peus (1958):p. 12, fig. 17.

Diagnosis. Rs very short; R4+5 five times longer than Rs; R4 nearly as long as R4+5; wing coloration pattern with isolated subapical spot and without spot on R2.

Redescription. Wing with original coloration pattern of dark clouds visible in medial and distal part; Sc rather long, ending opposite proximal third part of R3; R1

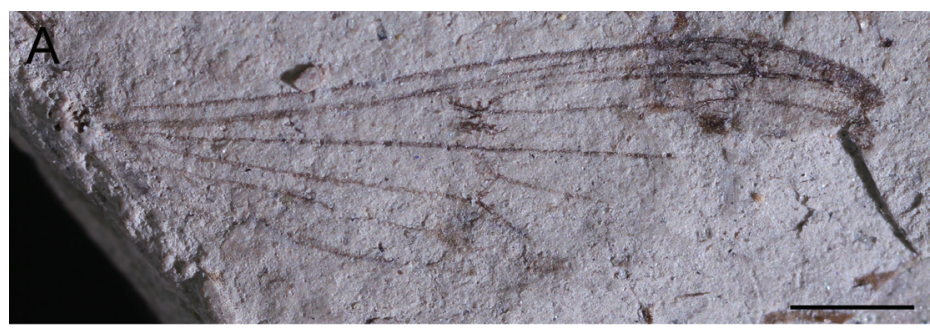

B
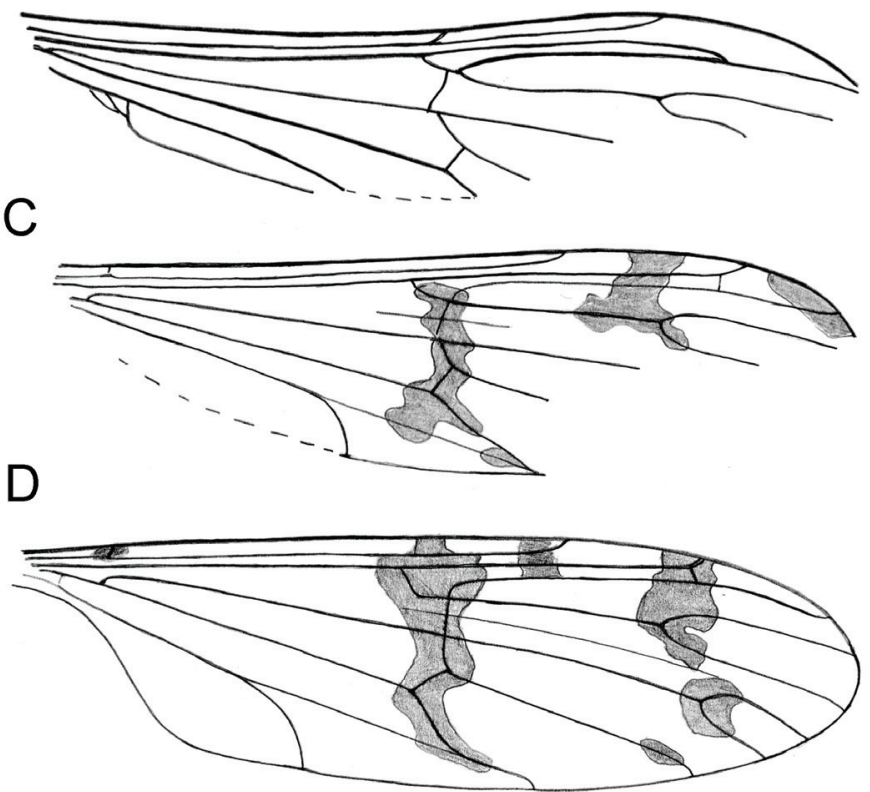

Figure 2 A-C. Ptychoptera deleta Novák, 1877 A photograph of holotype specimen No. NM-P947 B original line drawing of wing venation from Novák (1877) C line drawing of wing venation (reconstruction) D Ptychoptera agnes Krzemiński and Zwick, 1993, drawing of wing venation (scale bar represents $1 \mathrm{~mm}$ ). 
long; cross vein r-r (R2) at its about two lengths before tip of R1; Rs very short; R4+5 five times longer than Rs; R4 nearly as long as $\mathrm{R} 4+5$; cross vein $\mathrm{r}-\mathrm{m}$ just before forks of Rs and of M; distal part R5 and most part of medial veins not preserved, cross vein $\mathrm{m}$-cu about its length behind origin of $\mathrm{M} 3+4$; $\mathrm{A} 1$ rather long, its distalmost section strongly curved to posterior wing margin.

Dimensions. Length of wing fragment about $7 \mathrm{~mm}$, probable total length about $7.1 \mathrm{~mm}$; maximum width about $1.8 \mathrm{~mm}$.

Holotype. No. NM-P947 (imprint of nearly complete wing with medio-apical part missing, posterior wing margin is partially broken, venation well preserved with traces of original pattern of coloration). Specimen is housed in collection of National Museum in Prague, Czech Republic.

Age and layer. Early Miocene (Ottnangian/Karpatian), Cypris Formation (grey claystone) sensu Rojík (2004).

Discussion. We provide a re-description of the holotype specimen with several inaccurate characters in wing venation corrected in comparison to the original drawing of Novák, e.g., ending of R1 to anterior wing margin, indication of coloration pattern, A1 basally running parallel to $\mathrm{Cu}$ for long distance and ending in posterior wing margin, several missing or present cross-veins. Moreover, we supplement the description by the first photograph of this specimen (unavailable in 1877).

Unfortunately the single diagnostic wing character $(\mathrm{M} 1+2 \mathrm{fork})$ of the subfamily Ptychopterinae is not preserved. However, the wing venation pattern with very well visible crossvein $r-m$ positioned just before $M$ forking into $M 1+2$ and $M 3+4$, and original color pattern of $P$. deleta show considerable similarities to recent species of Ptychoptera. These are distinct apomorphic characters present only in this genus within the family Ptychopteridae. The wing venation of $P$. deleta is somewhat similar to the recent $P$. agnes Krzemiński \& Zwick, 1993 described from Hungary (Figs 2C-D). This fact is not surprising due to the Early Miocene age of our fossil (about 18-16 Ma) and considerably high morphological stability of insects (Nel and Prokop 2009; Hörnschemeyer et al. 2009). Finally, our present re-examination of the holotype confirms the great erudition of the Czech pioneer palaeontomologist Dr Ottomar Novák who correctly attributed the fossil species to the otherwise modern genus Ptychoptera.

\section{Acknowledgements}

This paper is devoted to the 75th anniversary of Prof. Alexandr Rasnitsyn, leader of Russian paleoentomological laboratory at Paleontological Institute RAS, Moscow. Authors are grateful to Elena Lukashevich, journal editor Dmitry Shcherbakov (both Palaeontological Institute RAS, Moscow), and anonymous reviewer for their insightful comments and suggestions to the early version of the manuscript. We are grateful to Kamil Zagoršek (National Museum in Praha) for the loan of the holotype specimen and Martin Fikáček (National Museum in Praha) for his kind help with translation from German. Special thank goes to Iwona Kania who kindly helped with scanning of 
line drawings to digital form. Second author (JP) acknowledges the research support from Grant Agency of the Czech Republic No. 205/08/0643 and Ministry of Education MSM 0021620828.

\section{References}

Alexander CP (1927) Diptera family Ptychopteridae. In: Wytsman P (Ed) Genera Insectorum 188: $1-12$.

Ansorge J, Schröder F (1999) Bittacomorphinae (Diptera: Ptychopteridae) aus der alttertiären Fur-Formation (Moler) von Dänemark. Studia dipterologica 6: 305-320.

Bůžek Č, Holý F, Kvaček Z (1996) Early Miocene flora of the Cypris Shale (western Bohemia). Acta Musei Nationalis Pragae, Series B, Historia naturalis 52: 1-72.

Evenhuis NL (1994) Catalogue of the Fossil Flies of the World (Insecta: Diptera). Backhuys Publishers, Leiden, ii + 600 pp.

Fejfar O (1974) Die Eomiden und Cricetiden (Rodentia, Mammalia) des Miozäns der Tschechoslowakei. Palaeontographica A, 146: 100-180.

Freiwald A, Willman R (1992) Insekten aus der Fur-Formation von Dänemark (Moler, ob. Paleozän/unt. Eozän?). 7. Ptychopteridae (Diptera). Meyniana 44: 179-87.

Hancock E.G., Marcos-Garcia M.A., Rotheray GE (2006) Ptychopteridae - a family of flies (Diptera) new to the Neotropical Region and description of a new species. Zootaxa 1351: 61-68.

Handlirsch A (1909) Zur Phylogenie und Flügelmorphologie der Ptychopteriden (Dipteren). Annalen des K.K. Naturhistorischen Hofmuseums Wien 23: 263-272.

Hörnschemeyer T, Wedmann S, Poinar G (2009) How long can insect species exist? Evidence from extant and fossil Micromalthus beetles (Insecta: Coleoptera). Zoological Journal of the Linnean Society 158: 300-311.

Kalugina NS (1989) New Mesozoic psychodomorph dipteran insects from Siberia (Diptera: Eoptychopteridae, Ptychopteridae). Paleontologicheskii Zhurnal 1989(1): 65-77. [in Russian]

Krzeminski W (1992) Triassic and Lower Jurassic stage of Diptera evolution. Mitteilungen der schweizerischen entomologischen Gesellschaft 65: 39-59.

Krzemiński W and Krzemińska E (2003) Triassic Diptera: descriptions, revisions and phylogenetic relations. Acta zoologica cracoviensia 46(suppl.-Fossil Insects): 153-184.

Lukashevich ED (1993) New Eoptychopteridae (Diptera: Psychodomorpha) from the Jurassic of Asia. Paleontological Journal 27 (1A): 103-122.

Lukashevich ED (1995) First pupae of the Eoptychopteridae and Ptychopteridae from the Mesozoic of Siberia. Paleontological Journal 29 (4): 164-171.

Lukashevich ED (2008) Ptychopteridae (Insecta: Diptera): History of its study and limits of the family. Paleontological Journal 42: 66-74.

Lukashevich ED, Ansorge J, Krzemiński W, Krzeminska E (1998) Revision of Eoptychopteridae (Diptera: Eoptychopteridae). Polskie Pismo Entomologiczne 67: 311-343. 
Lukashevich ED, Coram RA, Jarzembowski EA (2001) New true flies (Insecta: Diptera) from the Lower Cretaceous of southern England. Cretaceous Research 22 (4): 451-460. doi: $10.1006 /$ cres.2001.0265

Mlíkovský J (1996) Tertiary avian localities of the Czech Republic. Acta Universistatis Carolinae Geologica 39(1995): 551-557.

Nel A, Prokop J (2009) Go to the species in paleoentomology: illusion or necessity. Mémoires de la Société Entomologique de France 8 (2009): 49-55.

Novák O (1877) Fauna der Cyprisschiefer des Egerer Tertiärbeckens. Sitzungsberichte der Koeniglichen Akademie der Wissenschaften, Mathematisch-Naturwissenschaftliche Classe 76: 71-96.

Obrhelová N, Obrhel J (1983) [Biostratigraphy of Miocene strata overlying the main browncoal seam in the Cheb and Sokolov basins.] Acta Universitatis Carolinae Geologica 3: 171-192. [in Czech with English summary]

Obrhelová N, Obrhel J (1987) Paläoichthyologie und Paläoökologie des kontinentalen Tertiärs und Quartärs der ČSSR. Zeitschrift für Geologische Wissenschaften, Berlin 15 (1987): 709-731.

Peus F (1958) 10b. Familie Liriopeidae. In: Lindner E (Ed) Die Fliegen der paläarktischen Region 3(1) Lief. 200: 10-44.

Podenas S (2007) First phantom crane flies (Diptera, Ptychopteridae) from Baltic amber (Eocene). Proceedings of the Academy of Natural Sciences of Philadelphia 156: 195-198. doi: 10.1635/0097-3157(2007)156[195:FPCFDP]2.0.CO;2

Prokop J (2003) Remarks on palaeoenviromental changes based on reviewed Tertiary insect associations from the Krušné hory piedmont basins and the České středohoří Mts. in northwestern Bohemia (Czech Republic). Acta Zoologica Cracoviensia 46 (suppl. - Fossil Insects): 329-344.

Prokop J, Fleck G, Nel A (2003) New dragonflies from the Lower Miocene (Ottnangian/Karpatian) of the Cypris Shale in western Bohemia (Odonata: Libellulidae). Neues Jahrbuch für Geologie und Paläontologie Monatshefte 2003: 561-576.

Ren D, Krzemiński W (2002) Eoptychopteridae (Diptera) from the Middle Jurassic of China. Annales Zoologici 52: 207-210.

Rojík P (2004) New stratigraphic subdivision of the Tertiary in the Sokolov Basin. Journal of the Czech Geological Society 49: 173-185. 